Darapsky and Mueller. ${ }^{1}$ The $3.5 \mathrm{~g}$. of crude nitroso compound, obtained in the above experiment, were dissolved in $29 \mathrm{cc}$. of $50 \%$ alcohol, and reduced at $10^{\circ}$ by introducing $5 \circ \mathrm{g}$. of $5^{\circ}$ sodium amalgam in small portions, with constant shaking. After the amalgam had become exhausted, ro cc. of water were added and the solution, poured off from the mercury, was boiled a few minutes. On making the solution just acid with $\mathrm{HCl}, 0.6 \mathrm{~g}$. of almost pure hydrazinodiacetic acid crystallized out. Reduction of the aqueous solution, from which the $3.5 \mathrm{~g}$. of nitroso compound separated, with $25 \mathrm{~g}$. of amalgam yielded an additional $0.3 \mathrm{~g}$. of the hydrazino acid. The substance proved identical in every respect with a sample of hydrazinodiacetic acid, made from hydrazine hydrate and monochloroacetic acid. ${ }^{2}$ The following analysis was made on the sample obtained in the above reduction and purified by recrystallization from water:

$$
\text { Calc. for } \mathrm{C}_{4} \mathrm{H}_{8} \mathrm{O}_{4} \mathrm{~N}_{2}: \mathrm{N}, 18.92 \text {; found: } \mathrm{N}, 18.88 \text {. }
$$

Austrin, Texas.

[CONTRIBUTION FROM THE CHEMICAL LABORATORY OF THE UNIVERSTTY OF TEXAS.]

\title{
THE NITROSO DERIVATIVES OF SEMICARBAZINODIACETIC ACID ESTERS.
}

BY J. R. BAILEY AND D. F. SNYDER.

Received February 8, 1915.

Introduction.

In studying the relation between the derivatives of hydrazinodiacetic acid and those of iminodiacetic acid, we had occasion to repeat the work of Bailey and Read ${ }^{3}$ on the action of nitrous acid on methyl semicarbazinodiacetate. They showed that in this reaction methyl iminodiacetate is formed, but did not succeed in isolating the intermediary nitroso compound, $\mathrm{NH}_{2} \mathrm{CON}(\mathrm{NO}) \mathrm{N}\left(\mathrm{CH}_{2} \mathrm{COOCH}_{3}\right)_{2}$. We find that this primary reaction product can be isolated and analyzed, but after a few hours standing undergoes spontaneous decomposition as follows:

$\mathrm{NH}_{2} \mathrm{CON}(\mathrm{NO}) \mathrm{N}\left(\mathrm{CH}_{2} \mathrm{COOCH}\right)_{2}=\mathrm{NH}_{2} \mathrm{CON}\left(\mathrm{CH}_{2} \mathrm{COOCH}_{3}\right)_{2}+\mathrm{N}_{2} \mathrm{O}$

The constitution of this new substance as methyl ureidodiacetate was es tablished by its synthesis from the hydrochloride of methyl iminodiacetate ${ }^{4}$ and potassium cyanate, as well as by its conversion to esters of hydantoino-I-acetic acid. ${ }^{5}$ In the sodium alcoholate condensation of methyl ureidodiacetate to a hydantoin, ${ }^{6}$ it was found that the methyl

1 Ber., 4I, 356 (1908).

2 J. prakt. Chem., [2] 83, 27 I (I9II); ThIS Journal, 36, I747 (I914).

${ }_{3}$ This Journal, 36, 1747 (1914).

${ }^{4}$ Rec. trav. chim., 27, 287 (1908).

${ }^{5}$ See foregoing article of Bailey and Snyder.

${ }^{6}$ Cf. Am. Chem. J., 28, 386 (I g02). 
ureido ester in ethyl alcohol with sodium ethoxide gave the ethyl ester of hydantoino-I-acetic acid, while sodium methoxide acted on the substance in methyl alcohol with the formation of the methyl ester of hydantoino-I-acetic acid. Bailey and Read observed a similar interchange of alkyls in the triazine condensation of methyl and ethyl semicarbazinodiacetate. ${ }^{1}$

Fischer, in describing the spontaneous decomposition of nitrosodiethylsemicarbazide, $\mathrm{NH}_{2} \mathrm{CON}(\mathrm{NO}) \mathrm{N}\left(\mathrm{C}_{2} \mathrm{H}_{5}\right)_{2}$, states "these crystals can be filtered and washed, but not dried; after remaining a short time in a desiccator, they lose their yellow color and change with gas evolution to a colorless, strongly alkaline liquid." 2 It is probable that unsym.-diethylurea, $\mathrm{NH}_{2} \mathrm{CON}\left(\mathrm{C}_{2} \mathrm{H}_{5}\right)_{2}$ was formed in this decomposition, and that the alkaline reaction was due to small amounts of diethylamine and ammonia. Furthermore, in describing the nitroso derivative of methylphenylsemicarbazide, which he was able to analyze, Fischer states: "It melts at $77^{\circ}$ with slight gas evolution and changes to a dark yellow oil, which was not further investigated." 3 Here the decomposition would be expected to yield unsym.-methylphenylurea. Thiele $e^{4}$ has shown that $\alpha$-nitrosophenylhydrazine on heating in nitrobenzene solution decomposes quantitatively into nitrous oxide and aniline,

$$
\mathrm{C}_{6} \mathrm{H}_{5} \mathrm{~N}(\mathrm{NO}) \mathrm{NH}_{2}=\mathrm{C}_{6} \mathrm{H}_{5} \mathrm{NH}_{2}+\mathrm{N}_{2} \mathrm{O} \text {. }
$$

Darapsky and Prabhaker ${ }^{5}$ observed a similar decomposition on heating the esters of $\alpha$-nitrosohydrazínoacetic acid in vacuo, in that nitrous oxide and esters of aminoacetic acid were formed,

$$
\mathrm{NH}_{2} \mathrm{~N}(\mathrm{NO}) \mathrm{CH}_{2} \mathrm{COOR}=\mathrm{N}_{2} \mathrm{O}+\mathrm{NH}_{2} \mathrm{CH}_{2} \mathrm{COOR} \text {. }
$$

Further investigation may show that, in conformity with the above uniform decomposition of nitroso hydrazino derivatives, it is possible in all such cases to eliminate nitrous oxide and unite the two rests joined to either side of the $=$ NNO complex.

The decomposition in water solution of the nitroso derivatives of all secondary semicarbazino derivatives thus far investigated proceeds with the hydrolysis of the ureido group and the evolution of nitrous oxide, as first observed by Fischer, $e$. $g$.,

$\mathrm{NH}_{2} \mathrm{CON}(\mathrm{NO}) \mathrm{N}\left(\mathrm{C}_{2} \mathrm{H}_{5}\right)_{2}+\mathrm{H}_{2} \mathrm{O}=\mathrm{NH}_{3}+\mathrm{CO}_{2}+\mathrm{N}_{2} \mathrm{O}+\mathrm{NH}\left(\mathrm{C}_{2} \mathrm{H}_{6}\right)_{2}$.

In conformity with this reaction, Bailey and Read found that methyl nitrososemicarbazinodiacetate in water solution decomposes normally as follows:

\footnotetext{
1 This Journal, 36, I754 (1914).

2 Ann., 199,.313 (1879).

${ }^{3}$ Ibid., I90, 165 (1878).

4 Ber., 41, 2809 (1908).

5 Ibid., 45, I658 (I9I2).
} 
$\mathrm{NH}_{2} \mathrm{CON}(\mathrm{NO}) \mathrm{N}\left(\mathrm{CH}_{2} \mathrm{COOCH}_{3}\right)_{2}+\mathrm{H}_{2} \mathrm{O}=$

$$
\mathrm{NH}_{3}+\mathrm{CO}_{2}+\mathrm{N}_{2} \mathrm{O}+\cdot \mathrm{NH}\left(\mathrm{CH}_{2} \mathrm{COOCH}_{3}\right)_{2}
$$

Experimental Part.

Methyl Nitrososemicarbazinodiacetate,

$\mathrm{NH}_{2} \mathrm{CON}(\mathrm{NO}) \mathrm{N}\left(\mathrm{CH}_{2} \mathrm{COOCH}\right)_{2}$. - Methyl semicarbazinodiacetate is dissolved in five times its weight of water, a concentrated solution of one mol. of $\mathrm{NaNO}_{2}$ added, and to this mixture kept cool in ice water, one mol of $3 \mathrm{~N} \mathrm{H}_{2} \mathrm{SO}_{4}$ gradually added with constant shaking. The nitroso compound requires about one hour for complete separation. It is readily soluble in alcohol, chloroform, and benzene, and is best purified by recrystallization from acetic ether. In order that it may dry quickly, it is well to wash the nitroso compound with ether after filtering from the acetic ether. From acetic ether, it crystallizes in very characteristic tetragonal prisms of a deep yellow color, which melt with decomposition at $67^{1} / 2^{\circ}$. Even after careful purification, the substance must be kept in a cool place to preserve it sufficiently long for an analysis. 22.67.

Calc. for $\mathrm{C}_{7} \mathrm{H}_{12} \mathrm{O}_{6} \mathrm{~N}_{4}: \mathrm{C}, 33.87 ; \mathrm{H}, 4.84 ; \mathrm{N}, 22.58$; found: $\mathrm{C}, 34.07 ; \mathrm{H}, 4.99 ; \mathrm{N}$,

Ethyl Nitrososemicarbazinodiacetate.-This nitroso derivative is prepared similarly to the above methyl ester, with the exception that here it is possible to work with the semicarbazide in an equal weight of water and, "therefore, to obtain a better yield of the nitroso compound, about $\mathrm{I} .4 \mathrm{~g}$. from $2 \mathrm{~g}$. of ethyl semicarbazinodiacetate. This compound possesses a remarkable difference in its solubilities in ether within a short range of temperature. It was found that a saturated solution of the nitroso compound in ether at $27^{\circ}$, on cooling to $5^{\circ}$, solidified so compactly that the test tube in which it was contained could be inverted without any loss of substance. The nitroso derivative was obtained in this way in a very pure state as a matted mass of hair-like needles, melting with decomposition at $60^{\circ}$.

\section{Calc. for $\mathrm{C}_{9} \mathrm{H}_{16} \mathrm{O}_{6} \mathrm{~N}_{4}: \mathrm{N}, 20.29$; found: $\mathrm{N}, 20.25$.}

Methyl Ureidodiacetate from Methyl Nitrososemicarbazinodiacetate. - Of the above nitroso compounds the methyl ester is the better suited for the isolation of the ureidodiacetate. For the preparation of methyl ureidodiacetate, methyl nitrososemicarbazinodiacetate is allowed to stand over sulfuric acid in a desiccator, slightly open to the air. After a short time, depending no doubt in a large measure on the temperature, gas evolution commences with a rise of temperature and the decomposition proceeds quickly to completion. The residue is then, washed with a very little chloroform, which removes a small amount of smear and effects crystallization, and the ureido compound is then readily purified by crystallization from alcohol. Methyl ureidodiacetate is difficultly 
soluble in ether and benzene, and readily soluble in the other common solvents with the exception of petrolic ether. From alcohol it crystallizes. in prisms with dome-shaped end faces and melts at $145^{\circ}$ with the elimination of alcohol and formation of methyl hydantoino-I -acetate.

Methyl Ureidodiacetate from the Hydrochloride of Methyl Iminodiacetate and Potassium Cyanate.-Potassium cyanate and the hydrochloride of methyl iminodiacetate react readily in concentrated aqueous. solution. The ureido compound separates out in large part, and a further amount can be obtained by evaporating the solution to dryness and extracting with alcohol. This preparation proved identical with the decomposition product of methyl nitrososemicarbazinodiacetate.

Calc. for $\mathrm{C}_{7} \mathrm{H}_{12} \mathrm{O}_{5} \mathrm{~N}_{2}: \mathrm{C}, 4 \mathrm{I} .18 ; \mathrm{H}, 5.88 ; \mathrm{N}, 13.73$; found: $\mathrm{C}, 4 \mathrm{I} .20 ; \mathrm{H}, 5.95 ; \mathrm{N}$, I3.9I,

Conversion of Methyl Ureidodiacetate to the Methyl and Ethyl Esters to Hydantoino-I-acetic Acid.-One gram of methyl ureidodiacetate in Io cc. of ethyl alcohol is treated with a solution of sodium ethoxide prepared from $0.12 \mathrm{~g}$. of sodium. After the alcoholic solution has stood for one hour, it is neutralized with hydrochloric acid, the alcohol distilled off in vacuo, and the residue extracted with chloroform. The substance thus prepared and purified by recrystallization from benzene, proved identical with ethyl hydantoino-I-acetate, described in the foregoing article. Methyl ureidodiacetate in methyl alcohol gave with sodium methoxide the corresponding hydantoino methyl ester. However, a better method of preparing the latter substance is to heat methyl ureidodiacetate at $170^{\circ}$ as long as alcohol is given off. The methyl hydantoino$\mathrm{I}$-acetate, purified by recrystallization from alcohol was obtained in prisms, melting at $\mathrm{II}^{\circ}$. Jongkees, who first prepared this hydantoin, gave $107^{-108^{\circ}}$ as its melting point. As a further confirmation of the constitution of the substance, as obtained by us, a complete analysis was made.

Calc. for $\mathrm{C}_{6} \mathrm{H}_{8} \mathrm{O}_{4} \mathrm{~N}_{2}: \mathrm{C}, 41.86 ; \mathrm{H}, 4.65 ; \mathrm{N}, 16.28$; found: $\mathrm{C}, 42.05 ; \mathrm{H}, 4.72 ; \mathrm{N}$, 16.44 .

Ethyl Ureidodiacetate.-The decomposition of ethyl nitrososemicarbazinodiacetate yielded a viscous residue, which on dissolving in benzene and precipitating with petrolic ether, separated as a smear. However, after this smear had stood several weeks, large irregular shaped crystals separated out. An attempt was made to identify this product, which was obtained in poor yield, as ethyl ureidodiacetate by synthesizing it in a way similar to that employed above for methyl ureidodiacetate. For this purpose the hydrochloride of ethyl iminodiacetate, made according to the method of Jongkees, was treated in aqueous solution with potassium cyanate and a substance extracted with chloroform from the solution, corresponding in solubilities and,crystalline form to the decompo- 
sition product of ethyl nitrososemicarbazinodiacetate. However, the latter substance melted at $80^{\circ}$ and the ureido compound from the hydrochloride of ethyl iminodiacetate at $76^{\circ}$. On mixing the two preparations, dissolving the mixture in chloroform, and precipitating with petrolic ether, the substance obtained melted at $80^{\circ}$. It would, therefore, seem that ethyl ureidodiacetate can exist in two forms, but our available supply of ethyl semicarbazinodiacetate did not admit of the preparation of sufficient of the higher melting stable form to enable a further confirmation of this view by an analysis. Both preparations were found readily soluble in the common solvents with the exception of ether and petrolic ether and both separated from chloroform solution on addition of petrolic ether in characteristic flat prisms with dome-shaped end faces. The following analysis was made on the preparation from the hydrochloride of ethyl iminodiacetate and potassium cyanate:

Austin, Texas.

$$
\text { Calc. for } \mathrm{C}_{9} \mathrm{H}_{16} \mathrm{O}_{3} \mathrm{~N}_{2}: \mathrm{N}, \mathrm{I} 2.07 \text {; found: N, I2.28. }
$$

[FROM THE INSTITUTE DOYEN, PARIS.]

\section{A STUDY OF THE NINHYDRIN REACTION IN RELATION TO THE AGE AND HABITS OF INDIVIDUALS.}

BY Jokicht TAKamine, JR.

Received January 21, 1915.

According to Abderhalden, the blood contains a specific "Shutzferment," 1 which lies latent in the blood but ever ready to be brought into activity when the proper conditions prevail. Such conditions are the numerous various diseases common to the human and animal kingdom. He has shown this by experiment-The ferment only being brought into mobility when a certain specific substrạtum was brought into contact with it and often no other. ${ }^{2}$

But it is not easy to conceive of the blood containing a vast number of ferments each labeled for a certain disease or group of diseases. Be that as it may, Abderhalden has shown that the blood contains a ferment only brought into activity by some special and extraneous agency. Following his method of procedure, I have determined that there is a ferment, the amount of which predominates in people of old age as compared to the amount of said ferment in young people. The amount of this ferment seems to be in direct ratio to the age of the person.

To incite the release of this ferment I have used human fibroma tissue with best results, but ordinary connective tissue will also cause similar action. I have also noted with interest that the habits of the persons whose serum was tested had a direct result upon the amount of ferment

1 Handbuch der Biochemischen Arbeitsmethoden, I912, Vol. 6, p. 223.

${ }^{2} Z$. physiol. Chem., 8i, 9o. 